\title{
PENGARUH FASILITAS BELAJAR, MOTIVASI BELAJAR, DAN KEDISIPLINAN TERHADAP PENGETAHUAN TENTANG FUNGSI PAJAK PADA SISWA KELAS XI SMK NEGERI 1 LAMBOYA
}

\author{
Matius Matti Nunu ${ }^{1}$, Deni Nugroho Setyabudi ${ }^{2}$ \\ 1Pendidikan Ekonomi, IKIP Budi Utomo \\ e-mail: matiusnunu@gmail.com \\ 2Pendidikan Ekonomi, IKIP Budi Utomo
}

\begin{abstract}
Knowledge of subject matter is very important possessed by every student, because thus the student learning process results in a change in cognitive aspects from not understanding to becoming more understanding after students learn. However, there are several factors that influence the level of students' knowledge about subject matter, including the factors of learning facilities, learning motivation and student discipline in learning. The objectives of this study are: (1) to determine the effect of learning facilities on students' knowledge of the tax function, (2) to determine the effect of learning motivation on students' knowledge of the tax function, (3) to determine the effect of discipline on students' knowledge of the tax function, (4) to determine the effect of learning facilities, learning motivation, and discipline simultaneously on students' knowledge of the tax function. This research method is quantitative research. The object of this research is the XI grade students of SMK Negeri 1 Lamboya in semester 2 of the 2017/2018 Academic Year, totaling 55 students. Data collection techniques in this study used a questionnaire (to evaluate learning facility variables, learning motivation and discipline), as well as written tests (to evaluate students knowledge of the tax function). The research data were analyzed statistically using multiple regression analysis techniques. The results of the analysis of the data of this study indicate that: (1) learning facilities have a significant effect on knowledge about tax functions in students. (2) learning motivation has a significant effect on knowledge about the function of tax on students. (3) discipline has a significant effect on knowledge of the tax function on students. (4) learning facilities, learning motivation, and discipline simultaneously have a significant effect on the knowledge of the tax function on students.
\end{abstract}

Keywords: Learning Facilities, Learning Motivation, Discipline, Knowledge of Tax Functions 


\begin{abstract}
Abstrak
Pengetahuan terhadap materi pelajaran sangat penting dimiliki oleh setiap siswa, karena dengan demikian maka proses belajar siswa membuahkan hasil yaitu perubahan aspek kognitif dari belum paham menjadi lebih paham setelah siswa belajar. Namun, ada beberapa faktor yang berpengaruh terhadap tinggi rendahnya pengetahuan siswa tentang materi pelajaran, antara lain faktor fasilitas belajar, motivasi belajar dan kedisiplinan siswa dalam belajar. Tujuan penelitian ini adalah: (1) mengetahui pengaruh fasilitas belajar terhadap pengetahuan siswa tentang fungsi pajak, (2) mengetahui pengaruh motivasi belajar terhadap pengetahuan siswa tentang fungsi pajak, (3) mengetahui pengaruh kedisiplinan terhadap pengetahuan siswa tentang fungsi pajak, (4) mengetahui pengaruh fasilitas belajar, motivasi belajar, dan kedisiplinan secara simultan terhadap pengetahuan siswa tentang fungsi pajak. Metode penelitian ini merupakan penelitian kuantitatif. Objek pada penelitian ini adalah siswa kelas XI SMK Negeri 1 Lamboya semester 2 Tahun Ajaran 2017/2018, yang berjumlah 55 siswa. Teknik pengumpulan data penelitian ini menggunakan kuesioner (untuk mengevaluasi variabel fasilitas belajar, motivasi belajar dan kedisiplinan), serta tes tulis (untuk mengevaluasi pengetahuan siswa tentang fungsi pajak). Data-data penelitian dianalisis secara statistik menggunakan teknik analisis regresi berganda. Hasil analisis data penelitian ini menunjukkan, bahwa: (1) fasilitas belajar berpengaruh signifikan terhadap pengetahuan tentang fungsi pajak pada siswa. (2) motivasi belajar berpengaruh signifikan terhadap pengetahuan tentang fungsi pajak pada siswa. (3) kedisiplinan berpengaruh signifikan terhadap pengetahuan tentang fungsi pajak pada siswa. (4) fasilitas belajar, motivasi belajar, dan kedisiplinan secara simultan berpengaruh signifikan terhadap pengetahuan tentang fungsi pajak pada siswa.
\end{abstract}

Kata kunci : Fasilitas Belajar, Motivasi Belajar, Kedisiplinan, Pengetahuan Fungsi Pajak 


\section{PENDAHULUAN}

Keberhasilan siswa dalam belajar dapat dilihat dari pengetahuan siswa terhadap materi yang telah dipelajarinya. Menurut Arifin (2010), pada penilaian akademik, pengetahuan siswa diukur melalui tes yang dilakukan setelah kegiatan pembelajaran usai. Hasil tes ditunjukkan melalui nilai atau skor yang diberikan guru terhadap tugas siswa dan ulangan-ulangan atau ujian yang ditempuhnya.

Uraian di atas menjelaskan bahwa pengetahuan siswa merupakan salah satu indikator yang dapat digunakan untuk mengukur keberhasilan proses belajar siswa. Salah satu aspek yang dipelajari siswa dalam kegiatan pembelajaran di sekolah adalah ekonomi. Adapun salah satu materi ekonomi yang diajarkan kepada siswa adalah tentang fungsi pajak.

Pajak merupakan suatu pungutan yang merupakan hak prerogatif pemerintah, pungutan tersebut didasarkan pada Undang-Undang, pemungutannya dapat dipaksanakan kepada subyek pajak yang mana tidak ada balas jasa yang langsung dapat ditunjukkan penggunaannya (Mangkoesoebroto, 2016). Definisi pajak menurut Undang-Undang Nomor 16 tahun 2009 tentang perubahan keempat atas UndangUndang Nomor 6 tahun 1983 tentang Ketentuan Umum dan Tata Cara Perpajakan pada pasal 1 ayat 1 berbunyi pajak adalah kontribusi wajib kepada negara yang terutang oleh orang pribadi atau badan yang bersifat memaksa berdasarkan
Undang-Undang, dengan tidak mendapatkan imbalan secara langsung dan digunakan untuk keperluan negara bagi sebesarbesarnya kemakmuran rakyat (Mardiasmo, 2016:3).

Berdasarkan hasil observasi awal yang peneliti lakukan di SMK Negeri 1 Lamboya dan informasi yang diperoleh dari guru mata pelajaran ekonomi kelas XI diketahui bahwa materi fungsi pajak sudah diberikan kepada siswa, namun masih banyak siswa yang penguasaan materinya (pengetahuan) sangat kurang. Hal tersebut menunjukkan bahwa masih banyak siswa yang belum mengetahui dengan baik tentang materi fungsi pajak, sedangkan dalam kegiatan pembelajaran, siswa dikatakan berhasil apabila telah mampu mengetahui dan memahami materi yang telah dipelajarinya. Kondisi ini mencerminkan bahwa proses pembelajaran ekonomi materi fungsi pajak di kelas XI SMK Negeri 1 Lamboya belum berhasil dengan maksimal, karena pengetahuan siswa tentang fungsi pajak masih rendah. Padahal proses pembelajaran sudah dilaksanakan dengan sebaik mungkin, namun realita menunjukkan bahwa pengetahuan siswa tentang fungsi pajak masih sangat kurang.

Terdapat beberapa faktor yang dapat mempengaruhi pengetahuan siswa tenatng materi yang dipelajarinya yang menunjukkan prestasi belajarnya. Menurut Yamin (2015), prestasi belajar ditentukan oleh dua faktor, yaitu faktor internal dan faktor eksternal, dimana faktor internal dapat meliputi keadaan 
jasmani (fisik yang sehat) dan keadaan rohani (intelegensi, kemauan, bakat, daya ingat, daya konsentrasi), sedangkan faktor eksternal dapat meliputi hal-hal yang bersumber dari lingkungan keluarga, lingkungan sekolah, lingkungan masyarakat. Hal tersebut didukung oleh hasil penelitian Herawati dan Widiastuti (2013) yang menyimpulkan bahwa faktor-faktor yang dapat mempengaruhi prestasi belajar siswa yaitu motivasi, lingkungan sosial yang terdiri dari relasi antar anggota keluarga dan relasi siswa dengan siswa, psikologi yang terdiri dari EQ (Emotional Quotation), kebiasaan belajar, perhatian, modernitas individu, sikap, serta kesiapan dan faktor IQ (Intellectual Quotation).

Sunadi (2012) mengemukakan bahwa "motivasi belajar siswa dan kelengkapan fasilitas belajar merupakan faktor terpenting yang dapat mempengaruhi prestasi belajar siswa". Selain faktor-faktor di atas, keberhasilan proses belajar siswa juga ditentukan oleh kedisiplinan siswa dalam belajar. Hal ini sesuai dengan pernyataan Prasojo (2014) menyatakan bahwa kedisiplinan merupakan faktor yang sangat penting dan menentukan keberhasilan proses belajar siswa, karena dengan disiplin mempelajari materi maka pengetahuan siswa terhadap materi tersebut akan semakin baik.

Penelitian terdahulu yang dilakukan Budiono (2016) berjudul "Pengaruh Motivasi dan Fasilitas Belajar Terhadap Prestasi Belajar Siswa", yang menyimpulkan bahwa motivasi dan fasilitas belajar berpengaruh positif dan signifikan terhadap perubahan pengetahuan siswa tentang materi yang dipelajarinya. Kelengkapan fasilitas dan motivasi yang tinggi dari siswa untuk belajar secara otomatis juga akan menyebabkan siswa disiplin dalam belajar. Hal ini didukung oleh hasil penelitian Prasojo (2014:1) yang menyimpulkan bahwa kedisiplinan belajar merupakan faktor yang berpengaruh terhadap prestasi belajar siswa yaitu penguasaan (pengetahuan) siswa tentang materi pelajaran.

Dari hasil penelitian-penelitian terdahulu maka dirumuskan hipotesis sebagai berikut:

$\mathrm{H}_{1}$ : Diduga fasilitas belajar secara parsial berpengaruh terhadap pengetahuan tentang fungsi pajak pada siswa kelas XI SMK Negeri 1 Lamboya.

$\mathrm{H}_{2}$ : Diduga motivasi belajar secara parsial berpengaruh terhadap pengetahuan tentang fungsi pajak pada siswa kelas XI SMK Negeri 1 Lamboya.

$\mathrm{H}_{3}$ : Diduga kedisiplinan secara parsial berpengaruh terhadap pengetahuan tentang fungsi pajak pada siswa kelas XI SMK Negeri 1 Lamboya.

$\mathrm{H}_{4}$ : Diduga fasilitas belajar, motivasi belajar, dan kedisiplinan secara simultan berpengaruh terhadap pengetahuan tentang fungsi pajak pada siswa kelas XI SMK Negeri 1 Lamboya. 


\section{METODE PENELITIAN}

Jenis penelitian ini merupakan penelitian kuantitatif, karena datadata yang diperoleh dalam penelitian ini berupa angka atau skor-skor, serta dalam penelitian ini terdapat hipotesis yang perlu diuji kebenarannya secara statistik. Rancangan yang digunakan dalam penelitian ini adalah korelasional, karena penelitian ini bertujuan untuk mengetahui pengaruh fasilitas belajar, motivasi belajar, dan kedisiplinan terhadap pengetahuan tentang fungsi pajak pada siswa kelas XI SMK Negeri 1 Lamboya.

Populasi dalam penelitian ini adalah siswa kelas XI SMK Negeri 1 Lamboya semester 2 Tahun Ajaran 2017/2018, yang terdiri dari dua kelas yaitu XI A (27 siswa) dan XI B (28 siswa), sehingga total populasi berjumlah 55 siswa. Teknik sampling penelitian ini menggunakan total sampling. Berdasarkan hal tersebut, maka karena jumlah populasi penelitian ini kurang dari 100, maka seluruhnya diambil sebagai sampel sehingga penelitian ini merupakan penelitian populasi. Dengan demikian, maka sampel penelitian ini adalah seluruh siswa kelas XI SMK Negeri 1 Lamboya semester 2 Tahun Ajaran 2017/2018, yang total berjumlah 55 siswa.

Teknik pengumpulan data dalam penelitian ini menggunakan angket. Kisi-kisi angket yang dimaksud, yaitu:

Tabel 1. Kisi-kisi Angket

\begin{tabular}{|c|l|l|l|l|}
\hline N & Variabel & Indikator & Sumber & $\begin{array}{c}\text { Kategori } \\
\text { Jawaban } \\
\text { / Skor }\end{array}$ \\
\hline 1. & $\begin{array}{l}\text { Fasilitas } \\
\text { belajar }\end{array}$ & a. Ruang kelas & $\begin{array}{c}\text { Sugiyant } \\
\text { b. Perabot }\end{array}$ & SS $=5$ \\
\hline
\end{tabular}

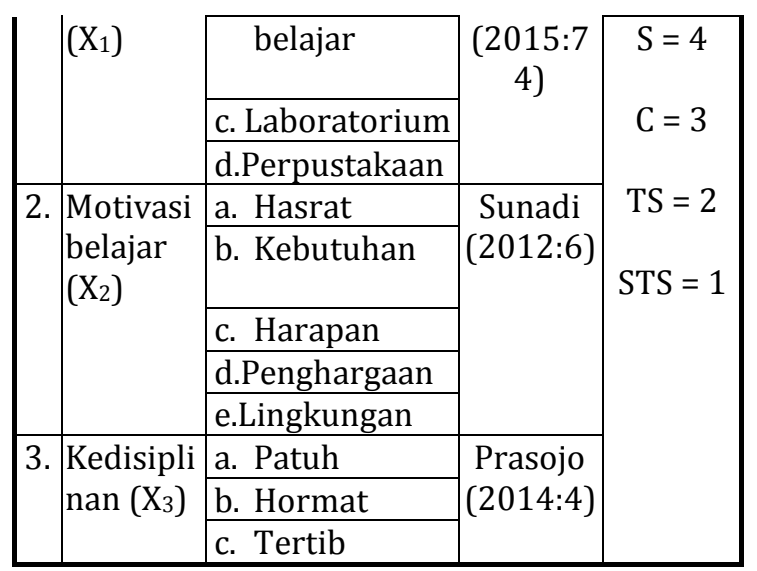

Jumlah pernyataan yang disajikan sebanyak 25 butir dan menggunakan skor untuk setiap jawaban yang dipilih responden. Skor jawaban yang diperoleh merupakan skala ordinal agar dapat dianalisis dan diangkakan menggunakan skala Likert (5 tingkatan, yaitu 1 sampai 5). Rincian pemberian skor tiap jawaban

Teknik analisis data penelitian ini meliputi uji validitas dan realiabilitas, uji asumsi klasik (uji autokorelasi, multikolinearitas, heteroskedastisitas, normalitas), serta uji multiple regression (regresi linier ganda) untuk menguji hipotesis.

\section{HASIL DAN PEMBAHASAN PENELITIAN \\ Uji Normalitas}

Berdasarkan uji normalitas dengan metode Normal Probability Plots, diketahui data menyebar di sekitar garis diagonal dan mengikuti arah garis diagonal. Hal ini menunjukkan bahwa data kuesioner dalam penelitian ini terdistribusi secara normal sehingga model regresi ini telah memenuhi asumsi normalitas. Hal tersebut dikarenakan sampel yang dipilih dalam penelitian 
ini adalah homogen dan memiliki karakteristik yang hampir sama sehingga sampel memiliki pandangan yang hampir sama atau serupa mengenai fasilitas belajar yang ada di sekolah, motivasinya untuk belajar, serta kedisiplinannya dalam belajar, sehingga hal tersebut tidak menyebabkan adanya atau timbulnya perbedaan jawaban yang signifikan antara sampel yang satu dengan yang lain.

\section{Uji Autokorelasi}

Berdasarkan

hasil

uji autokorelasi, diketahui nilai DurbinWatson sebesar 1,083. Nilai DurbinWatson tersebut mendekati angka 2, yang berarti tidak ada masalah autokorelasi atau tidak terdapat autokorelasi. Uji autokorelasi ini dilakukan untuk mendeteksi apakah terjadi korelasi antara anggota serangkaian observasi yang diurutkan menurut waktu (data time series) atau ruang (data cross section).

\section{Uji Multikolinearitas}

\section{Berdasarkan} hasil uji multikolinearitas, diketahui nilai Tolerance seluruh variabel bebas $\left(\mathrm{x}_{1}\right.$, $\mathrm{x}_{2}$ dan $\mathrm{x}_{3}$ ) lebih dari 0,1 dan nilai VIF kurang dari 10. Dengan demikian, maka dapat disimpulkan dalam model regresi ini tidak terjadi masalah multikolinearitas. Hal ini menunjukkan bahwa antara variabel fasilitas belajar, motivasi belajar dan kedisiplinan tidak saling berhubungan. Jika ketiganya saling berhubungan maka variabel itu tidak ortogonal (nilai korelasi antar sesama variabel bebas sama dengan nol).

\section{Uji Heteroskedastisitas}

Berdasarkan

heteroskedastisitas dengan menggunakan metode pengujian scatter plots regression, diketahui nilai error (titik-titik) menyebar di atas dan di bawah 0 pada sumbu $Y$, sehingga model regresi tidak terjadi heteroskedastisitas, justru terjadi homoskedastisitas, sehingga model regresi (fasilitas belajar, motivasi belajar dan kedisiplinan) layak digunakan untuk menguji pengaruhnya terhadap pengetahuan siswa tentang fungsi pajak.

\section{Hasil Uji Multiple Regressions}

Berdasarkan analisis multiple regressions menggunakan SPSS, maka dapat dilihat pada tabel berikut:

Tabel 2. Rangkuman Hasil Analisis Multiple Regressions

Coefficients $^{a}$

\begin{tabular}{|c|c|c|c|c|c|}
\hline \multirow[b]{2}{*}{ Model } & \multicolumn{2}{|c|}{$\begin{array}{r}\text { Unstandardi } \\
\text { zed } \\
\text { Coefficients }\end{array}$} & \multirow{2}{*}{ 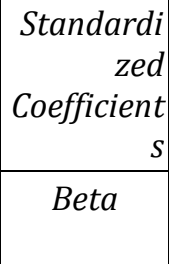 } & \multirow{2}{*}{$t$} & \multirow{2}{*}{ Sig. } \\
\hline & $B$ & $\begin{array}{l}\text { Std. } \\
\text { Error }\end{array}$ & & & \\
\hline $1 \mid \begin{array}{c}\text { (Consta } \\
n t)\end{array}$ & $\begin{array}{c}53.10 \\
6\end{array}$ & $\begin{array}{c}38.18 \\
8\end{array}$ & & $\begin{array}{c}1.39 \\
1\end{array}$ & $\begin{array}{c}0.02 \\
7\end{array}$ \\
\hline $\mathrm{x} 1$ & 0.113 & 0.484 & 0.030 & $\begin{array}{c}0.23 \\
3\end{array}$ & $\begin{array}{c}0.04 \\
3\end{array}$ \\
\hline $\mathrm{x} 2$ & 1.037 & 0.954 & 0.152 & $\begin{array}{c}1.08 \\
7\end{array}$ & $\begin{array}{c}0.02 \\
8\end{array}$ \\
\hline x3 & 6.342 & 1.452 & 0.605 & $\begin{array}{c}4.36 \\
7\end{array}$ & $\begin{array}{c}0.00 \\
0\end{array}$ \\
\hline
\end{tabular}

a. Dependent Variable: $\mathrm{y}$

Berdasarkan Tabel 2, maka dapat disusun persamaan regresinya sebagai berikut:

$Y=a+b_{1} X_{1}+b_{2} X_{2}+b_{3} X_{3}$

$Y=53,106+0,113+1,037+6,342$ 
Berdasarkan persamaan regresi di atas, maka dapat dideskripsikan, sebagai berikut:

1. Koefisien $a=53,106$, yang berarti apabila variabel-variabel X sama dengan nol maka diperkirakan pengetahuan siswa tentang fungsi pajak mengalami kenaikan sebesar $53,106$.

2. Koefisien $b_{1} X_{1}=0,113$, yang menunjukkan adanya pengaruh yang positif antara fasilitas belajar terhadap pengetahuan tentang fungsi pajak pada siswa kelas XI SMK Negeri 1 Lamboya. Hal tersebut juga berarti bahwa semakin lengkap fasilitas belajar yang ada di sekolah maka pengetahuan siswa tentang fungsi pajak akan mengalami peningkatan sebesar 0,113. Dengan demikian, dapat disimpulkan keadaan ruang kelas yang nyaman, kelengkapan perabot belajar, kelengkapan sarana laboratorium dan perpustakaan merupakan indikator dari variabel fasilitas belajar yang dapat mempengaruhi pengetahuan tentang fungsi pajak pada siswa kelas XI SMK Negeri 1 Lamboya.

3. Koefisien $b_{2} X_{2}=1,037$, yang menunjukkan adanya pengaruh yang positif antara motivasi belajar terhadap pengetahuan tentang fungsi pajak pada siswa kelas XI SMK Negeri 1 Lamboya. Hal tersebut juga berarti bahwa semakin tinggi motivasi belajar yang dimiliki siswa maka pengetahuannya tentang fungsi pajak juga akan mengalami peningkatan sebesar 1,037. Dengan demikian, dapat disimpulkan bahwa hasrat siswa untuk berhasil dalam proses belajarnya, kebutuhan dalam belajar, harapan yang ingin dicapai, penghargaan yang ingin diraih, serta adanya lingkungan belajar yang kondusif merupakan indikator dari variabel motivasi belajar yang dapat mempengaruhi pengetahuan tentang fungsi pajak pada siswa kelas XI SMK Negeri 1 Lamboya.

4. Koefisien $b_{3} X_{3}=6,342$, yang menunjukkan adanya pengaruh yang positif antara kedisiplinan terhadap pengetahuan tentang fungsi pajak pada siswa kelas XI SMK Negeri 1 Lamboya. Hal tersebut juga berarti bahwa semakin tinggi tingkat kedisiplinan siswa dalam belajar maka pengetahuannya tentang fungsi pajak juga akan mengalami peningkatan sebesar 6,342. Dengan demikian, dapat disimpulkan bahwa sikap siswa yang mematuhi tata tertib sekolah, sikap hormat kepada seluruh warga di sekolah, serta sikap siswa untuk menjaga ketertiban belajar merupakan indikator dari variabel kedisiplinan yang dapat mempengaruhi pengetahuan tentang fungsi pajak pada siswa kelas XI SMK Negeri 1 Lamboya.

Setelah melihat hasil analisis di atas seperti diuraikan di atas, maka dapat diketahui bahwa seluruh variabel bebas (independent) berpengaruh terhadap variabel terikat 
(dependent). Pengaruh variabel bebas bisa dilihat berdasarkan ketepatannya (nilai yang paling signifikan) dari masing-masing variabel bebas, yaitu variabel fasilitas belajar $\left(\mathrm{X}_{1}\right)$ memiliki pengaruh lebih kecil terhadap pengetahuan siswa tentang fungsi pajak (Y), karena nilai koefisien $\mathrm{X}_{1}$ $(0,113)$ lebih kecil daripada variabel motivasi belajar $\left(\mathrm{X}_{2}\right)$ yang memiliki nilai koefisien 1,037 dan variabel kedisiplinan $\left(\mathrm{X}_{3}\right)$ yang memiliki nilai koefisien tertinggi 6,342 , maka 0,113 $<1,037<6,342$.

\section{Koefisien Determinasi}

Tabel 3. Model Summary

\begin{tabular}{|c|c|c|c|c|}
\hline Model & $R$ & $\begin{array}{c}R \\
\text { Square }\end{array}$ & $\begin{array}{c}\text { Adjusted } R \\
\text { Square }\end{array}$ & $\begin{array}{l}\text { Std. Error of } \\
\text { the Estimate }\end{array}$ \\
\hline 1 & $0.553^{\mathrm{a}}$ & 0.306 & 0.265 & 15.28154 \\
\hline
\end{tabular}

a. Predictors: (Constant), x3, x1, x2

b. Dependent Variable: $\mathrm{y}$

Berdasarkan Tabel 3 di atas, diketahui nilai Adjusted $R$ Square sebesar 0,265. Nilai ini menunjukkan besarnya sumbangan yang diberikan seluruh variabel bebas terhadap variabel terikat, yaitu 26,5\%. Sementara itu, kontribusi lain (73,5\%) diberikan atau disumbangkan oleh variabel lain yang tidak diteliti/ tidak diungkap dalam penelitian ini. Faktorfaktor yang tidak diungkap tersebut menurut Yamin (2015) antara lain kondisi jasmani siswa, kondisi rohani (kecerdasan, kemauan, bakat, daya ingat, dan daya konsentrasi), serta lingkungan keluarga dan lingkungan masyarakat.

\section{Pengujian Hipotesis}

Hipotesis Pertama

Berdasarkan Tabel 2, diketahui nilai Sig. variabel fasilitas belajar $(0,043)<$ 0,05 , maka $\mathrm{H}_{0}$ ditolak dan $\mathrm{H}_{1}$ diterima.
Dengan demikian, maka dapat disimpulkan fasilitas belajar secara parsial berpengaruh signifikan terhadap pengetahuan tentang fungsi pajak pada siswa kelas XI SMK Negeri 1 Lamboya.

Hipotesis Kedua

Berdasarkan Tabel 2, diketahui nilai Sig. variabel motivasi belajar $(0,028)<$ 0,05 , maka $\mathrm{H}_{0}$ ditolak dan $\mathrm{H}_{2}$ diterima. Dengan demikian, maka dapat disimpulkan motivasi belajar secara parsial berpengaruh signifikan terhadap pengetahuan tentang fungsi pajak pada siswa kelas XI SMK Negeri 1 Lamboya.

Hipotesis Ketiga

Berdasarkan tabel 2, diketahui nilai Sig. variabel kedisiplinan $(0,000)<$ 0,05 , maka $\mathrm{H}_{0}$ ditolak dan $\mathrm{H}_{3}$ diterima. Dengan demikian, maka dapat disimpulkan kedisiplinan secara parsial berpengaruh signifikan terhadap pengetahuan tentang fungsi pajak pada siswa kelas XI SMK Negeri 1 Lamboya.

Hipotesis Keempat

\section{Tabel 4. Hasil Uji Anova}

ANOVA $^{b}$

\begin{tabular}{|l|c|c|c|c|c|}
\hline Model & $\begin{array}{c}\text { Sum of } \\
\text { Squares }\end{array}$ & df & $\begin{array}{c}\text { Mean } \\
\text { Square }\end{array}$ & F & Sig. \\
\hline 1 Regressio & 5242.936 & 3 & 1747.64 & 7.48 & 0.000 \\
$n$ & & & 5 & 4 & $\mathrm{a}$ \\
Residual & 11909.79 & 5 & 233.525 & & \\
1 & 1 & & & \\
Total & 17152.72 & 5 & & & \\
& 7 & 4 & & & \\
\hline
\end{tabular}

a. Predictors: (Constant), x3, x1, x2

b. Dependent Variable: $\mathrm{y}$

Berdasarkan Tabel 4, diketahui nilai Sig. $(0,000)<0,05$, maka $\mathrm{H}_{0}$ ditolak dan $\mathrm{H}_{4}$ diterima. Dengan demikian, maka dapat disimpulkan bahwa 
fasilitas belajar, motivasi belajar, dan kedisiplinan secara simultan berpengaruh signifikan terhadap pengetahuan tentang fungsi pajak pada siswa kelas XI SMK Negeri 1 Lamboya.

\section{Pembahasan}

\section{Pengaruh Fasilitas Belajar Terhadap Pengetahuan Tentang Fungsi Pajak}

Pengaruh fasilitas belajar terhadap pengetahuan siswa tentang fungsi pajak dapat dilihat dari hasil multiple regressions penelitian ini yang menunjukkan variabel fasilitas belajar (x1) memiliki nilai Sig. 0,043<0,05, maka $\mathrm{H}_{0}$ ditolak dan $\mathrm{H}_{1}$ diterima. Dengan demikian, maka dapat disimpulkan fasilitas belajar berpengaruh signifikan terhadap pengetahuan tentang fungsi pajak pada siswa kelas XI SMK Negeri 1 Lamboya. Dari hasil analisis data tersebut juga diketahui nilai koefisien $b_{1} X_{1}$ sebesar 0,113 .

Uraian di atas menunjukkan adanya pengaruh yang positif antara fasilitas belajar terhadap pengetahuan tentang fungsi pajak pada siswa kelas XI SMK Negeri 1 Lamboya. Semakin lengkap fasilitas belajar yang ada di sekolah maka pengetahuan siswa tentang fungsi pajak akan mengalami peningkatan sebesar 0,113. Dengan demikian, dapat disimpulkan bahwa keadaan ruang kelas yang nyaman, kelengkapan perabot belajar, kelengkapan sarana laboratorium dan perpustakaan merupakan indikator dari variabel fasilitas belajar yang dapat mempengaruhi pengetahuan tentang fungsi pajak pada siswa kelas XI SMK Negeri 1 Lamboya.

\section{Pengaruh Motivasi Belajar Terhadap Pengetahuan Tentang Fungsi Pajak}

Pengaruh motivasi belajar terhadap pengetahuan siswa tentang fungsi pajak dapat dilihat dari hasil multiple regressions penelitian ini yang menunjukkan variabel motivasi belajar $\left(\mathrm{x}_{2}\right)$ memiliki nilai Sig. 0,028 < 0,05 , maka $\mathrm{H}_{0}$ ditolak dan $\mathrm{H}_{2}$ diterima. Dengan demikian, maka dapat disimpulkan motivasi belajar berpengaruh signifikan terhadap pengetahuan tentang fungsi pajak pada siswa kelas XI SMK Negeri 1 Lamboya. Dari hasil analisis data tersebut juga diketahui nilai koefisien $b_{2} X_{2}$ sebesar 1,037 .

Uraian di atas menunjukkan adanya pengaruh yang positif antara motivasi belajar terhadap pengetahuan tentang fungsi pajak pada siswa kelas XI SMK Negeri 1 Lamboya. Hal tersebut juga berarti bahwa semakin tinggi motivasi belajar yang dimiliki siswa maka pengetahuannya tentang fungsi pajak juga akan mengalami peningkatan sebesar 1,037. Dengan demikian, dapat disimpulkan bahwa hasrat siswa untuk berhasil dalam proses belajarnya, kebutuhan dalam belajar, harapan yang ingin dicapai, penghargaan yang ingin diraih, serta adanya lingkungan belajar yang kondusif merupakan indikator dari variabel motivasi belajar yang dapat mempengaruhi pengetahuan tentang fungsi pajak pada siswa kelas XI SMK Negeri 1 Lamboya. 


\section{Pengaruh Kedisiplinan Terhadap Pengetahuan Tentang Fungsi Pajak}

Pengaruh kedisiplinan terhadap pengetahuan siswa tentang fungsi pajak dapat dilihat dari hasil multiple regressions penelitian ini yang menunjukkan variabel kedisiplinan (х3) memiliki nilai Sig. 0,000 < 0,05, maka $\mathrm{H}_{0}$ ditolak dan $\mathrm{H}_{3}$ diterima. Dengan demikian, maka dapat disimpulkan kedisiplinan berpengaruh signifikan terhadap pengetahuan tentang fungsi pajak pada siswa kelas XI SMK Negeri 1 Lamboya. Dari hasil analisis data tersebut juga diketahui nilai koefisien $b_{3} X_{3}$ sebesar 6,342.

Uraian di atas menunjukkan ada pengaruh yang positif antara kedisiplinan terhadap pengetahuan tentang fungsi pajak pada siswa kelas XI SMK Negeri 1 Lamboya. Hal tersebut juga berarti bahwa semakin tinggi tingkat kedisiplinan siswa dalam belajar maka pengetahuannya tentang fungsi pajak juga akan mengalami peningkatan sebesar 6,342. Dengan demikian, dapat disimpulkan bahwa sikap siswa yang mematuhi tata tertib sekolah, sikap hormat kepada seluruh warga di sekolah, serta sikap siswa untuk menjaga ketertiban belajar merupakan indikator dari variabel kedisiplinan yang dapat mempengaruhi pengetahuan tentang fungsi pajak pada siswa kelas XI SMK Negeri 1 Lamboya.

\section{KESIMPULAN DAN SARAN}

Berdasarkan hasil analisis data dan pembahasan penelitian maka dapat dikemukakan kesimpulan bahwa Fasilitas Belajar berpengaruh signifikan terhadap Pengetahuan tentang Fungsi Pajak pada siswa kelas XI SMK Negeri 1 Lamboya.

Motivasi belajar berpengaruh signifikan terhadap pengetahuan tentang fungsi pajak pada siswa kelas XI SMK Negeri 1 Lamboya.

Kedisiplinan berpengaruh signifikan terhadap pengetahuan tentang fungsi pajak pada siswa kelas XI SMK Negeri 1 Lamboya.

Fasilitas belajar, motivasi belajar, dan kedisiplinan secara simultan berpengaruh signifikan terhadap pengetahuan tentang fungsi pajak pada siswa kelas XI SMK Negeri 1 Lamboya.

\section{Saran}

Bagi peneliti selanjutnya harus selektif memilih sampel dan memperluas ranah penelitian, misalnya meneliti seluruh siswa di SMK Negeri 1 Lamboya, sehingga hasil penelitian dapat digeneralisasikan.

Dapat menggunakan hasil penelitian ini sebagai referensi atau bahan acuan dalam upaya menyelenggarakan kegiatan penelitian serupa di kemudian hari.

\section{DAFTAR RUJUKAN}

Arifin. 2010. Penelitian Pendidikan: Pendekatan Kuantitatif \& Kualitatif. Yogyakarta: Lilin Persada Press.

Budiono, Bagus. 2016. Pengaruh Motivasi dan Fasilitas Belajar Terhadap Prestasi Belajar Sistem Kopling Siswa Kelas XI SMK Cipta Karya Prembun Kebumen. 
Jurnal Otomotif UMP, Vol. 7 No. 1, hal. 52-56.

Herawati, Immaculata \& Yuli Widiastuti. 2013. Analisis Faktor-faktor yang Mempengaruhi Prestasi Belajar Akuntansi. eJournal Universitas Negeri Malang, Vol. 1 No. 1, hal. 1-13.

Mangkoesoebroto, G. 2016. Ekonomi Publik. Cetakan ke-17. Yogyakarta: BPFE Yogyakarta (Anggota IKAPI).

Mardiasmo. 2016. Perpajakan Edisi Terbaru 2016.Yogyakarta: Penerbit ANDI.

Prasojo, Retmono Jazib. 2014. Pengaruh Perhatian Orang Tua dan Kedisiplinan Belajar Terhadap Prestasi Belajar Mata Pelajaran IPS. Jurnal Pendidikan Ekonomi IKIP Veteran Semarang, Vol. 2 No. 1, hal. 1-11.

Sugiyanto. 2015. Pengaruh Fasilitas Belajar, Lingkungan Keluarga, Lingkungan Sosial Terhadap Hasil Belajar IPS. Seminar Nasional Universitas PGRI Yogyakarta, Vol. 1 No. 1, hal. 7279.

Sugiyono. 2011. Statistik Untuk Penelitian. Cetakan ke-19. Bandung: CV. Alfabeta.

Sunadi, Lukman. 2012. Pengaruh Motivasi Belajar dan Pemanfaatan Fasilitas Belajar Terhadap Prestasi Belajar Siswa pada Mata Pelajaran Ekonomi Kelas XI IPS di SMA Muhammadiyah 2 Surabaya. Jurnal Pendidikan Ekonomi, Vol. 1 No. 1, hal. 1-19.
Yamin, Moh. 2015. Teori dan Metode Pembelajaran: Konsepsi, Strategi dan Praktik Belajar yang Membangun Karakter. Malang: Madani (Kelompok Intrans Publishing) Anggota IKAP 